Article

\title{
Freshening of a Coastal Karst Aquifer Revealed by the Temporal Changes in a Spring Water Composition (La Palme, Southern France)
}

\author{
Christophe Monnin ${ }^{1, *} \mathbb{\infty}$, Joseph Tamborski ${ }^{2,+}+\mathbb{D}$, Simon Bejannin ${ }^{2}$, Marc Souhaut ${ }^{2}$, \\ Manon Roques ${ }^{1}$, Philippe Olivier ${ }^{1}$ and Pieter van Beek ${ }^{2}$ \\ 1 Géosciences Environnement Toulouse (Université de Toulouse, CNRS, IRD, UPS), \\ Observatoire Midi Pyrénées, 14 Ave Edouard Belin, 31400 Toulouse, France; \\ mr.manon.roques@gmail.com (M.R.); philippe.olivier1531@orange.fr (P.O.) \\ 2 Laboratoire d'Etudes en Géophysique et Océanographie Spatiales (Université de Toulouse, CNES, CNRS, \\ IRD, UPS), Observatoire Midi Pyrénées, 14 Ave Edouard Belin, 31400 Toulouse, France; \\ joetamborski@gmail.com (J.T.); simon.bejannin@gmail.com (S.B.); marc.souhaut@legos.obs-mip.fr (M.S.); \\ Pieter.van-Beek@legos.obs-mip.fr (P.v.B.) \\ * Correspondence: christophe.monnin@get.omp.eu; Tel.: +33-561326130 \\ + Current Address: Department of Marine Chemistry and Geochemistry, \\ Woods Hole Oceanographic Institution, Woods Hole, MA 02536, USA.
}

Received: 15 April 2019; Accepted: 28 May 2019; Published: 3 June 2019

\begin{abstract}
Coastal karst aquifers are vulnerable to sea level rise and seawater intrusion. Knowledge of aquifer hydrological characteristics is therefore essential to managing this water resource. Long-term aquifer monitoring may not always be possible, especially in areas that humans frequent for recreational purposes. However, hydrological information can be deduced from the chemical composition of periodically sampled groundwaters. We characterized the complete chemical composition (temperature, $\mathrm{pH}$, salinity, ORP, $\mathrm{O}_{2}, \mathrm{Na}-\mathrm{K}-\mathrm{Ca}-\mathrm{Mg}$-Ba-Sr-Si-Cl-SO ${ }_{4}$-DIC, and DOC) of a brackish karstic spring located along the French Mediterranean coast (La Palme). The salinity of the spring water varied between 4 and 9 during the 2.5 year period of observation. Chemical analyses revealed that the spring is modified from modern seawater, as shown by Na-normalized dissolved element concentrations. Thermodynamic calculations of mineral saturation states (PHREEQC) point to aragonite and barite saturation and elevated equilibrium $\mathrm{CO}_{2}$ partial pressure. The simultaneous salinity minima and oxygen maxima coincide with extreme values of dissolved element concentrations. This indicates that variation in salinity and water chemistry in La Palme coastal aquifer is primarily driven by infiltration of fresh rainwater. This study shows that geochemical investigations can provide an alternative approach to characterizing the hydrological properties of coastal karst aquifers when wells or boreholes are not readily available.
\end{abstract}

Keywords: Karstic spring; coastal aquifer; seawater intrusion; hydrology; La Palme lagoon

\section{Introduction}

A large part of the world's population lives in coastal areas and as such depends on the water supply of coastal aquifers [1]. For example, the population density of the French Mediterranean coast is five times larger than the average population density of the metropolitan French territory (the nationwide population density was 113 inhabitants per square kilometer in 2009; www.CartesFrance.fr). This coast is impacted by seasonal anthropogenic pressures due to tourism (i.e., increased water demand, impact on the quality of the coastal seas and coastal aquifers, etc.). Besides the increase in demand linked to human activities, environmental factors such as sea level rise and seawater intrusion 
impact the coastal aquifers and are thus major threats to water resources in these densely populated areas [2-5]. Therefore, the hydrological regimes of coastal aquifers must be accurately characterized, especially in light of the challenges faced in a context of rapid climate change [2].

Coastal aquifers in Europe are located on different geological substrata [6]. Coastal karsts are quite common [6] and very diverse, especially along the Mediterranean coast $([7,8]$ and references therein). Hydrology and hydrogeology methods are most often employed to characterize coastal karst aquifers. Broadly, these methods include long-term monitoring of piezometers, wells or boreholes, and tracer tests to characterize the aquifer size and its hydrologic properties (response time to infiltration, transmissivity, storativity, etc.) $[9,10]$. By definition, springs are the surface outlet of aquifers, and their hydrologic regime is the result of the balance between the water inputs and outputs. Besides the study of the spring flow regime, hydrologic information can be obtained from chemical parameters such as salinity, $\mathrm{pH}$, element concentrations, or isotope ratios of the spring waters (e.g., [11-14]). Thus, geochemical investigations can provide an alternative approach to characterizing the hydrological properties of coastal karst aquifers, when wells or boreholes are not readily available.

From Marseille to the Spanish border, the French Mediterranean coast is lined with a series of coastal lagoons situated on sedimentary rocks, where karst formation favors subsurface water circulation $[7,15]$. The smallest of these lagoons is La Palme lagoon, which is listed in the European environmental protection program Natura 2000 (http://www.natura2000.fr/). The hydrological budget and inputs of submarine groundwater discharge (SGD) to La Palme lagoon have been thoroughly evaluated [16-19].

A brackish spring discharges into the lagoon on its Northern side. Whereas monitoring of the spring by installing data loggers and sensors for long periods is certainly a method of choice, this is practically impossible in the case of the La Palme lagoon karstic spring, as the pool of the spring (Figure 1) is frequently visited by locals and tourists during summer months, with a high probability of equipment disturbance and damage. In this study, we extract hydrological characteristics of the coastal karst aquifer from the chemical composition of spring water samples periodically measured over a 2.5-year period. In turn, we discuss the causes of the salinity variation of the spring water and investigate the role of the various contributions to the composition of the spring, namely, flow of paleo-groundwater, rain infiltration, and seawater intrusion. Beyond the particular case of this spring, we show how simple in-situ periodic measurements such as the salinity, oxygen content, and geochemical characterization of spring waters can provide insight into the hydrological characteristics of a coastal karstic aquifer.

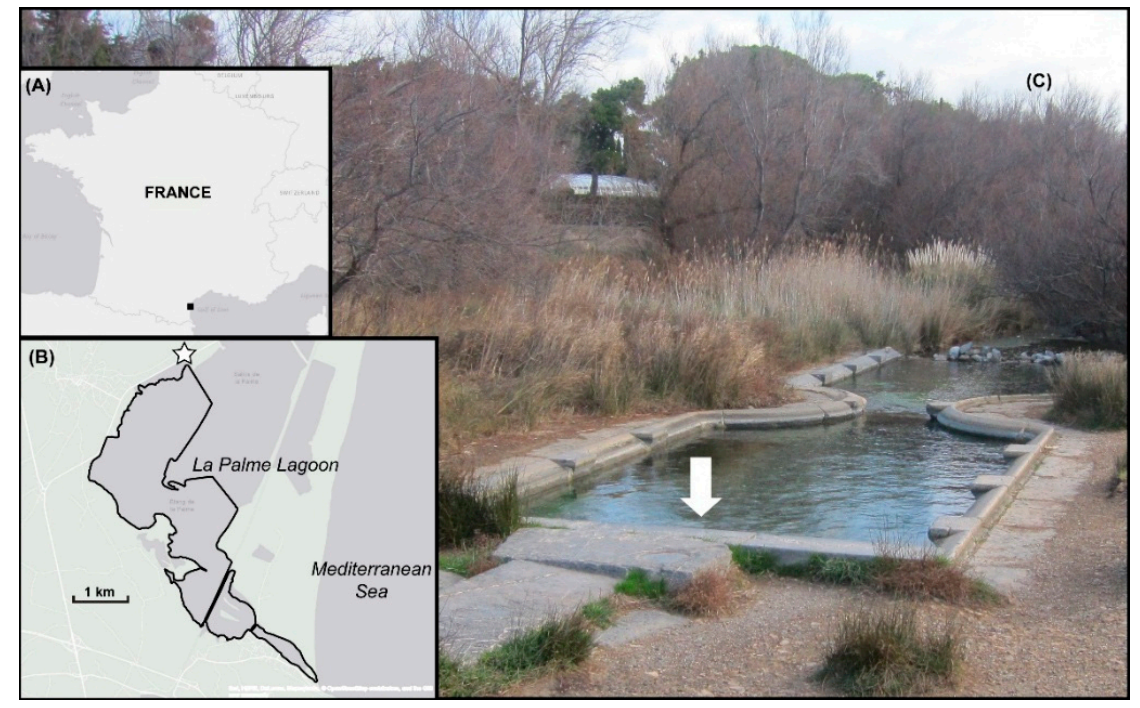

Figure 1. (A) Location of La Palme lagoon, in France, (B) location of the karstic groundwater spring located at the white star (Lavoir: no longer used wash-basin), and (C) Picture of the spring basin. The white arrow indicates the outlet of the spring. 


\section{Geology of the La Palme Watershed}

The La Palme watershed is located on the French Mediterranean coast between the Rhône River and the Pyrénées mountains, on the southeast side of the eastern margin of the Nappe des Corbières, a sedimentary formation in the foreland of the Eastern Pyrénées. When delimited from the topographic map, the watershed surface is $\sim 60 \mathrm{~km}^{2}$ with its maximum elevation of $596 \mathrm{~m}$ (Pic du Pied de Poul) at the southwest. The climate is Mediterranean, with hot and dry summer months and rainy, moderately cold winter periods. A small ephemeral stream (le Riou) drains the watershed from the Col de Feuilla to its outlet in the south-southwest part of La Palme lagoon, which was not flowing during the course of this study. The catchment is bordered on its southeast side by La Palme lagoon which collects the regional runoff. The lagoon is fed on one side by precipitation, runoff, and a karstic brackish groundwater spring ("Le Lavoir", the French word for wash-basin) which is located about three kilometers inland from the present-day Mediterranean Sea shoreline (Figure 1). This karstic spring discharges into the lagoon through a small stream flowing through perennial wetlands that are flooded when the water level of the lagoon is high. On the seaward side, the lagoon is influenced by flooding during storms and by surface water exchange through an inlet which is intermittently connected to the Mediterranean Sea.

Approximately two-thirds of the watershed (the center and northern parts) are made of Upper Jurassic-Lower Cretaceous limestone formations with a thickness of $\sim 200 \mathrm{~m}$ [20]. A section between the freeway and the lagoon (about a third of the surface of the watershed) is composed of $20 \mathrm{~m}$ thick layers of sands, sandstones, and calcareous molasses (Burdigalian), and of 1 to $4 \mathrm{~m}$ thick layers of Quaternary alluvium and colluvium. There is a small area of a few $\mathrm{km}^{2}$ located in the southwestern part of the basin between the Col de Feuilla and the Feuilla village that displays a very complex geology, with rock formations (mainly limestones and marls) belonging to the Nappe des Corbières lying on outcrops of Ordovician to Lias autochthonous formations. Large amounts of fibrous gypsum and anhydrite can be found in these latter formations.

The La Palme watershed roughly corresponds to the La Palme syncline, with the oldest formations (Paleozoic and Triassic-Liasic) on the southwest side and the more recent formations (Cretaceous-Miocene) in the center. The base contact of the Nappe des Corbières is one of the major structural features of this region, with allochthonous Lower Jurassic formations thrusted over the Triassic sole, which contains noticeable amounts of gypsum. The Mesozoic formations are characterized by an important fracture network of north-northwest to south-southeast oriented, hectometer-scale faults. Another east-west trending fracture network is also well represented, especially near the La Palme village. A salient feature of the watershed geology is the presence of salts like gypsum and anhydrite.

The Flandrian transgression (12,000 years BP) flooded the whole region up to $100 \mathrm{~m}$ high and thus may have introduced seawater into the coastal karsts $[7,8,21]$. It is unclear how this paleo-seawater exists as present day groundwater, as this transgression ceased more than 1500 years ago.

\section{Methods}

\subsection{In Situ Measurements and Timetable}

The spring was visited three times in 2016, and then 14 times from April 2017 to August 2018 at time intervals between two and six weeks the second year (Table 1). Salinity, pH, ORP (Oxidation-Reduction Potential in reference to the $\mathrm{Ag} / \mathrm{AgCl}$ standard), temperature, and dissolved oxygen were measured directly in the spring $\left(\sim 30 \mathrm{~cm}\right.$ depth) with the appropriate probes (respectively, SensoLyt ORP 900-P ${ }^{\circledR}$ for the redox potential, SenTix $940^{\circledR}$ for $\mathrm{pH}$, FDO $925^{\circledR}$ for dissolved oxygen, and IDS TetraCon $925^{\circledR}$ for conductivity-based salinity measurements in PSU) using a WTW Multi $3420^{\circledR}$ multimeter (Weilheim, Germany). Note that some parameters (e.g., $\mathrm{O}_{2}$, ORP, $\mathrm{pH}$ ) were not measured at all of the sampling dates (Table 1). Samples were collected without any chemical treatment (such as poisoning or acidification) in $60 \mathrm{~mL}$ LDPE vials after filtration with $0.45 \mu \mathrm{m}$ cellulose acetate filters. 
Table 1. Parameters measured in situ ( $\mathrm{T}, \mathrm{pH}, \mathrm{O}_{2}, \mathrm{ORP}$, salinity) and chemical composition of the karstic spring waters. DIC = Dissolved Inorganic Carbon. DOC =

Dissolved Organic Carbon (DIC and DOC are given in moles of carbon). ORP = Oxydo-Reduction Potential (with respect to the Ag/AgCl standard).

\begin{tabular}{|c|c|c|c|c|c|c|c|c|c|c|c|c|c|c|c|c|c|}
\hline \multirow{2}{*}{$\begin{array}{c}\text { Sampling } \\
\text { Date }\end{array}$} & $\mathbf{T}$ & $\mathrm{pH}$ & ORP & $\mathrm{O}_{2}$ & Salinity & DIC & DOC & $\mathrm{Na}$ & $\mathbf{K}$ & $\mathrm{Ca}$ & Mg & Sr & Ba & B & $\mathrm{Si}$ & $\mathrm{Cl}$ & $\mathrm{SO}_{4}$ \\
\hline & ${ }^{\circ} \mathrm{C}$ & & $m V$ & $m g / L$ & & $\mathrm{mmol} / \mathrm{L}$ & mmol/L & mmol/L & mmol/L & mmol/L & mmol/L & $\mu \mathrm{mol} / \mathrm{L}$ & nmol/L & $\mu \mathrm{mol} / \mathrm{L}$ & $\mu \mathrm{mol} / \mathrm{L}$ & mmol/L & $\mathrm{mmol} / \mathrm{L}$ \\
\hline 04/13/2016 & 19.3 & 6.930 & 251 & 4.9 & 8.8 & 6.23 & 0.06 & 111.1 & 2.4 & 7.6 & 12.5 & 26.1 & 178.8 & 74.1 & 107.7 & 135.2 & 7.6 \\
\hline $06 / 15 / 2016$ & 19.6 & & & & 8.9 & & & & & & & & & & & & \\
\hline 06/16/2016 & 19.1 & & & & 9.3 & & & & & & & & & & & & \\
\hline $11 / 16 / 2016$ & 18.9 & & 133 & & 7.4 & & & 80.7 & & 6.3 & & 27.0 & 158.4 & & 115.5 & & 6.8 \\
\hline $04 / 28 / 2017$ & 18.4 & 7.080 & & 7.4 & 4.8 & 5.51 & & 54.4 & 2.0 & 5.3 & 6.5 & & 275.7 & 48.7 & 103.3 & 71.3 & 4.4 \\
\hline 05/26/2017 & 18.8 & 7.143 & & 7.1 & 5.4 & 6.17 & & 67.6 & & 6.0 & & & 266.3 & & 101.7 & & 3.8 \\
\hline $06 / 22 / 2017$ & 18.6 & 7.105 & 138 & 6.7 & 6.0 & 5.85 & 0.09 & 72.1 & 1.6 & 6.0 & 8.4 & 40.6 & 128.3 & 57.9 & 103.4 & 89.6 & 5.5 \\
\hline 07/06/2017 & 18.6 & 7.210 & 116 & & 6.1 & 5.33 & 0.08 & 74.1 & 1.5 & 6.3 & 8.3 & 19.7 & 184.2 & 59.1 & 109.7 & 89.1 & 5.5 \\
\hline 08/30/2017 & 18.7 & 7.162 & & & 6.5 & 5.53 & & 75.2 & 1.6 & 5.7 & 9.2 & 39.1 & 306.6 & 65.2 & 128.3 & 97.2 & 5.9 \\
\hline $09 / 23 / 2017$ & 18.5 & & & & & 5.79 & & 82.1 & 1.7 & 6.4 & 9.3 & 46.6 & 225.9 & 63.3 & 118.8 & 100.5 & 6.1 \\
\hline $10 / 25 / 2017$ & 18.6 & 7.117 & & & 6.9 & 5.73 & & 83.4 & 1.7 & 6.6 & 9.8 & 46.8 & 232.0 & 66.8 & 118.2 & 104.2 & 6.3 \\
\hline $11 / 17 / 2017$ & 18.9 & 7.067 & 234 & 6.2 & 6.5 & 5.45 & & 80.1 & 1.6 & 6.4 & 9.2 & 48.0 & 246.1 & 65.5 & 120.6 & 98.3 & 6.0 \\
\hline 01/17/2018 & 18.4 & 7.015 & 150 & 5.8 & 7.0 & 6.09 & & 87.9 & 1.6 & 6.9 & 9.9 & 39.1 & 213.6 & 69.8 & 119.6 & 103.2 & 6.2 \\
\hline 03/13/2018 & 19.1 & 6.900 & 198 & 5.2 & 9.4 & 6.48 & & 117.9 & 2.3 & 8.2 & 13.2 & 62.1 & 228.3 & 91.7 & 126.7 & 140.8 & 8.5 \\
\hline $05 / 11 / 2018$ & 18.5 & 7.005 & & & 4.7 & 5.32 & & 57.4 & & 5.6 & & 43.0 & 84.8 & 50.5 & 87.6 & 73.4 & 4.4 \\
\hline $05 / 24 / 2018$ & 18.5 & 7.061 & 171 & 7.0 & 5.4 & 5.69 & & 70.1 & 1.1 & 6.0 & 7.9 & 44.1 & 95.5 & 60.4 & 91.4 & 85.4 & 5.1 \\
\hline 08/30/2018 & 18.8 & 6.885 & 155 & 6.0 & 8.0 & 6.16 & & 98.6 & 1.5 & 6.8 & 11.0 & 24.5 & 296.2 & 81.4 & 83.3 & 120.8 & 7.3 \\
\hline
\end{tabular}




\subsection{Chemical Analyses in the Laboratory}

All analyses were carried out at the Geosciences Environment Toulouse (GET) laboratory. The samples were analyzed within a few weeks after sampling. Cation $(\mathrm{Na}, \mathrm{K}, \mathrm{Ca}, \mathrm{Mg}, \mathrm{Ba}, \mathrm{Sr}$, and $\mathrm{Si})$ concentrations were measured using an ICP-OES Horiba Jobin Yvon Ultima $2^{\circledR}$ (Bensheim, Germany). The dissolved inorganic carbon content (DIC) and, for a few samples, the dissolved organic carbon content (DOC) were measured with a Shimadzu ${ }^{\circledR}$ analyzer (Kyoto, Japan). The analytical precisions for the ICP-OES and the carbon analyzer are $5 \%$ and $2 \%$, respectively. The anion concentrations $(\mathrm{Cl}$, $\mathrm{SO}_{4}$ ) were measured by ionic chromatography (Dionex ICS 2000 ${ }^{\circledR}$ liquid chromatographer;Sunnyvale, USA). The charge balance for all of the samples was below 3\%, except for the sample collected in May 2018 for which it was $11 \%$. We used three types of plots to evaluate the data: element concentrations versus time to see the temporal changes, element concentrations versus $\mathrm{Na}$ to see the effect of changing salinity (dilution), and Na-normalized concentrations versus time to highlight the temporal changes while avoiding dilution (salinity change).

\subsection{Thermodynamics: The Calculation of Mineral Saturation States}

The control of water composition by chemical equilibria between its dissolved components and minerals can be assessed by the calculation of the mineral saturation states $(\Omega)$ :

$$
\Omega=\log \left(\frac{Q}{K_{s p}}\right)
$$

In Equation (1), $Q$ is the mineral ionic product and $K_{s p}$ is its solubility product. The ionic product is the product of the activities of the constitutive elements or compounds of the mineral. The activity is the product of the concentration ( $\mathrm{m}$, expressed in the molality scale) of the given aqueous element or compound and its activity coefficient. The activity coefficient $(\gamma)$ takes into account the ionic environment (i.e., the composition of the aqueous solution defined by the molalities of the $n$ aqueous species) of the designated species. For the $i$ th species the definition of activity is (Equation (2)):

$$
a_{i}=m_{i} \cdot \gamma_{i}\left(m_{1}, m_{2}, \ldots m_{n}\right)
$$

Many software packages are dedicated to the calculation of the thermodynamic properties of aqueous solutions and minerals. They cinsist of a code that solves the problem of simultaneous multiple chemical equilibria from a database that contains the thermodynamic parameters of the aqueous and solid compounds (mineral solubility products, stability constants of aqueous complexes, Debye-Hückel parameters, etc.). Because there are many different ways to carry out such calculations, it is necessary to describe in some detail the methods and tools used in this work.

We used the PHREEQC code [22] along with several databases to calculate mineral saturation states. These databases differ by the number of minerals or aqueous species that they take into account. None of these databases can claim to be exhaustive. Some of them have been built for specific purposes like nuclear waste storage [23], clay-cement interactions [24,25], or the study of cold environments [26,27]. For a given compound, they may also differ by the values of the thermodynamic properties of this compound. In a given database, a mineral can appear under several polymorphic forms (for example $\alpha$ and $\beta$ quartz,) while only one form is reported under a generic name (for example quartz) in another database. For the example of quartz, the pK (log of the solubility product) of quartz in the PHREEQC.DAT data base is -4.17 [22]. The pK of $\alpha$-quartz is -3.90 and that of $\beta$-quartz -3.65 in the THERMODEMM.DAT data base [25]. This leads to differences of a factor of two or three between the solubility products of quartz and therefore to differences of 0.3 to 0.5 on the calculated saturation indices. Worse, the values of the solubility products at $25^{\circ} \mathrm{C}$ of the three forms of dolomite (dolomite, ordered dolomite, and disordered dolomite) included in a database such as 
THERMODEMM.DAT [25] differ by almost two orders of magnitude [28]. It is mandatory that the databases used in such thermodynamic calculations are reported.

We have mainly used the THERMODEMM.DAT V1.10 database in its PHREEQC format built by the French Geological Survey (BRGM), which contains an extensive (about 220) and regularly updated (http://thermoddem.brgm.fr/) list of minerals [25]. We have checked the saturation state of some minerals not included in this data base using other databases. For example, the mineral witherite $\left(\mathrm{BaCO}_{3}\right)$ is taken into account in the PHREEQC.DAT database. Ikaite $\left(\mathrm{CaCO}_{3} \cdot 6 \mathrm{H}_{2} \mathrm{O}\right)$ forms at temperatures close to freezing in marine environments [29] and, of all databases, is included only in the FREZCHEM.DAT database [26].

Equilibrium is reached when $\Omega$ is 0 . Supersaturation (mineral precipitation is possible) is indicated by positive $\Omega$ values and under-saturation (mineral dissolution possible) is indicated by negative values. In practice, one has to define a $\Omega$ range within which equilibrium is assumed. Ideally, this $\Omega$ range should not be left at the user's interpretation but should reflect the various uncertainties of the model (see discussions in [22,30]). We here retained an equilibrium criterion of $\Omega$ between -0.2 and +0.2 . Note that some authors (e.g., [31]) define an equilibrium $\Omega$ range for every mineral, which we do not consider in the present study.

A number of minerals that the calculations indicated as supersaturated are not known to form at low temperatures in the environment, nor have they been synthesized in the laboratory despite favorable thermodynamic conditions. This includes quartz, dolomite [28], and magnesite [32]. This adds to the uncertainty linked to their thermodynamic properties, as discussed above. For now, the precipitation (or lack of) mechanisms of these minerals are still unknown. As such, we restricted the discussion of the control of water composition through water-mineral interactions to Ca-carbonates (aragonite and calcite) and $\mathrm{Ca}, \mathrm{Sr}$, and Ba sulfates (barite, celestite, gypsum, and anhydrite).

\section{Results}

The salinity of the karstic spring displayed marked changes during the period of observation. Salinity was relatively high at $\sim 9$ during summer 2016 before decreasing to 4.8 in April 2017 and increasing back to 9.4 in March 2018, then dropping to 4.7 in April-May 2018 and increasing again (8) in August 2018 (Table 1; Figure 2). The salinity data displays two minimum values at the same period of the year (April-May) in 2017 and 2018. This begs one of the driving questions of this study: is the salinity variation of the karstic spring over time the result of (1) a brackish karst coastal aquifer being periodically diluted by rainfall, or (2) a fresh karst coastal aquifer subject to temporally variable seawater intrusion, or (3) a combination of (1) and (2)? There is no obvious relationship between precipitation and the salinity changes of the karstic spring (Figure 2). Water temperature of the spring water is fairly constant around $18.5^{\circ} \mathrm{C}$ and has no relationship with the air temperature. Spring water temperature dropped by $\sim{ }^{\circ} \mathrm{C}$ between April 2016 and April 2017, after which the temperature fluctuated between 18.5 and $19^{\circ} \mathrm{C}$ (Figure 2).

The concentrations of most dissolved elements displayed either maximum or minimum values at the same dates as the minimum values of salinity (Figure 3). Concentrations plotted versus Na content show that $\mathrm{Ca}, \mathrm{Mg}$, DIC, $\mathrm{SO}_{4}$, and $\mathrm{O}_{2}$ are correlated to salinity (or equivalently $\mathrm{Na}$ ), which is indicative of a dilution effect (Figure 4). Similar relationships are observed for temperature, $\mathrm{pH}, \mathrm{K}$, and $\mathrm{Si}$, albeit with greater variability. The $\mathrm{Ba}$ and $\mathrm{Sr}$ contents of the spring waters are highly variable (between 120 and $310 \mathrm{nmol} / \mathrm{L}$ for Ba and between 19 and $62 \mu \mathrm{mol} / \mathrm{L}$ for Sr), with no clear trend either in time or with $\mathrm{Na}$ content (Figures 3 and 4). Aqueous (or dissolved) $\mathrm{SiO}_{2}$ of the karstic spring has been found fairly constant with values between 100 and $130 \mu \mathrm{mol} / \mathrm{L}$ over a period of about two years, with a decrease to about $80 \mu \mathrm{mol} / \mathrm{L}$ starting in April 2018 (Figure 3).

The karstic spring salinity varied by a factor of roughly two, with a range between 4.8 and 9.4. The concentrations of $\mathrm{Mg}, \mathrm{K}$, and $\mathrm{SO}_{4}$ double when the salinity is multiplied by two. On the contrary, the Ca content increases by only $40 \%$ and the DIC by $15 \%$ when the salinity doubles. The concentration 
of a solute can be used to determine the dilution of a given water mass from two endmembers only when these endmembers are geochemically distinct.

The maximum $\mathrm{pH}$ value in the data set is observed for July 6, 2018 and is offset when compared to the salinity minimum which occurred on April 28, 2017 (Figure 3). The Na-normalized concentrations (Figure 5) remove the effect of dilution. Then the maximum in $\mathrm{pH} / \mathrm{Na}$ normalized concentration coincides with the maximum values for the other Na-normalized concentrations, notably $\mathrm{O}_{2} / \mathrm{Na}$, $\mathrm{DIC} / \mathrm{Na}, \mathrm{K} / \mathrm{Na}$, and $\mathrm{Ca} / \mathrm{Na}$, and with the two salinity minima, as well as a minimum for $\mathrm{SO}_{4} / \mathrm{Na}$ (Figure 5). Although brackish, the karstic spring waters do not exhibit elemental ratios characteristic of modern seawater. Their $\mathrm{Ca} / \mathrm{Na}, \mathrm{SO}_{4} / \mathrm{Na}, \mathrm{DIC} / \mathrm{Na}$, and $\mathrm{Sr} / \mathrm{Na}$ ratios are higher than those of standard seawater [33], aside from $\mathrm{K} / \mathrm{Na}$ and $\mathrm{Mg} / \mathrm{Na}$ (Figure 5).

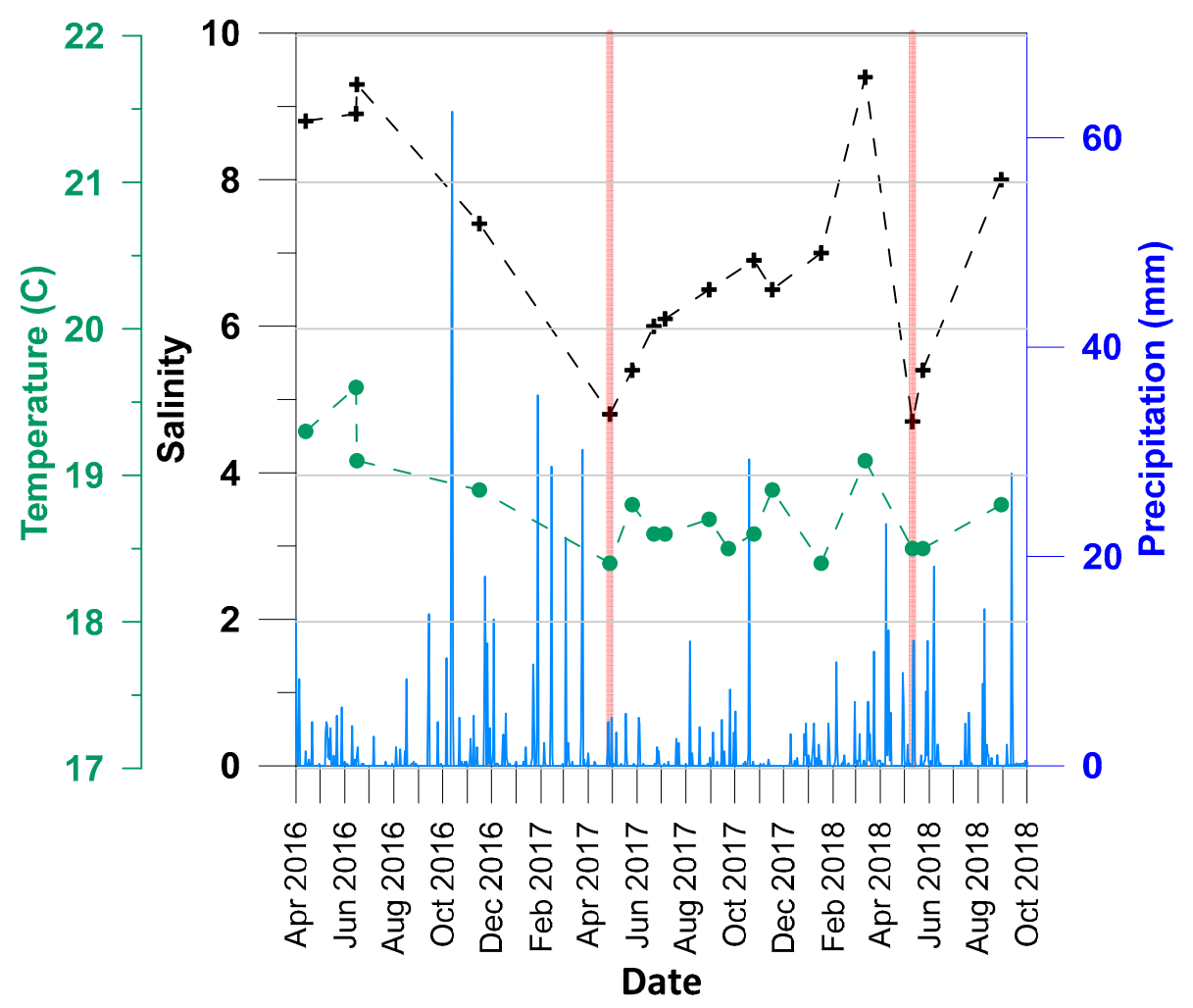

Figure 2. Salinity and temperature of the karstic spring waters and precipitation (daily averages recorded at the nearby Leucate station; https://www.infoclimat.fr/) during the period of observation (2016-2018). The two red vertical bars point to the two salinity minima.

Thermodynamic calculations show that the equilibrium $\mathrm{pCO}_{2}$ of the spring waters is approximately two orders of magnitude above the atmosphere (Figure 6), a common feature of karstic groundwaters (e.g., [31,34-37]). The $\log \left(\mathrm{pCO}_{2}\right)$ of the spring waters fluctuates over time, between -1.6 and -1.9 , due to changes in $\mathrm{pH}$ and DIC. The Ca-carbonates (calcite and aragonite) saturation states are within the range retained to define equilibrium at all dates, although aragonite is either close to the lower end of the equilibrium range or very slightly undersaturated, especially for August 2018 (Figure 6). Barite saturation is reached for most of the samples except those collected in May and August 2018 that respectively display under- and supersaturation. Gypsum and celestite were undersaturated for all dates. The under-saturation observed for May 2018 coincides with the lowest $\mathrm{Ba}$ and $\mathrm{SO}_{4}$ concentrations of the entire dataset, while on the contrary the supersaturation found for August 2018 results from the highest $\mathrm{Ba}$ and $\mathrm{SO}_{4}$ concentrations of the dataset. Repeated chemical analysis did not provide any further insight into these two points that are out of the trend derived from the samples collected at previous dates. Hydrological conditions following a precipitation event result in an increased flow-rate of karst groundwater, and subsequently of the karstic spring. In such conditions, 
the residence time of groundwater in the geologic formation is expected to be reduced, with the observed consequences on the chemical composition of the spring water. In the case of Ba, equilibrium with barite may not be attained when groundwater transit times are fast and residence times are short. This is one possible explanation for the barite under-saturation observed in May 2018. Groundwater flow may have thus been greater during May 2018 (second salinity minimum) in comparison to April 2017 (first observed salinity minimum), when barite was in equilibrium. The general pattern emerging from the data set is nevertheless a control of the calcium carbonate species (aqueous carbonate and bicarbonate) and barium contents of the waters by an equilibrium with $\mathrm{CaCO}_{3}$ minerals and barite in the aquifer.
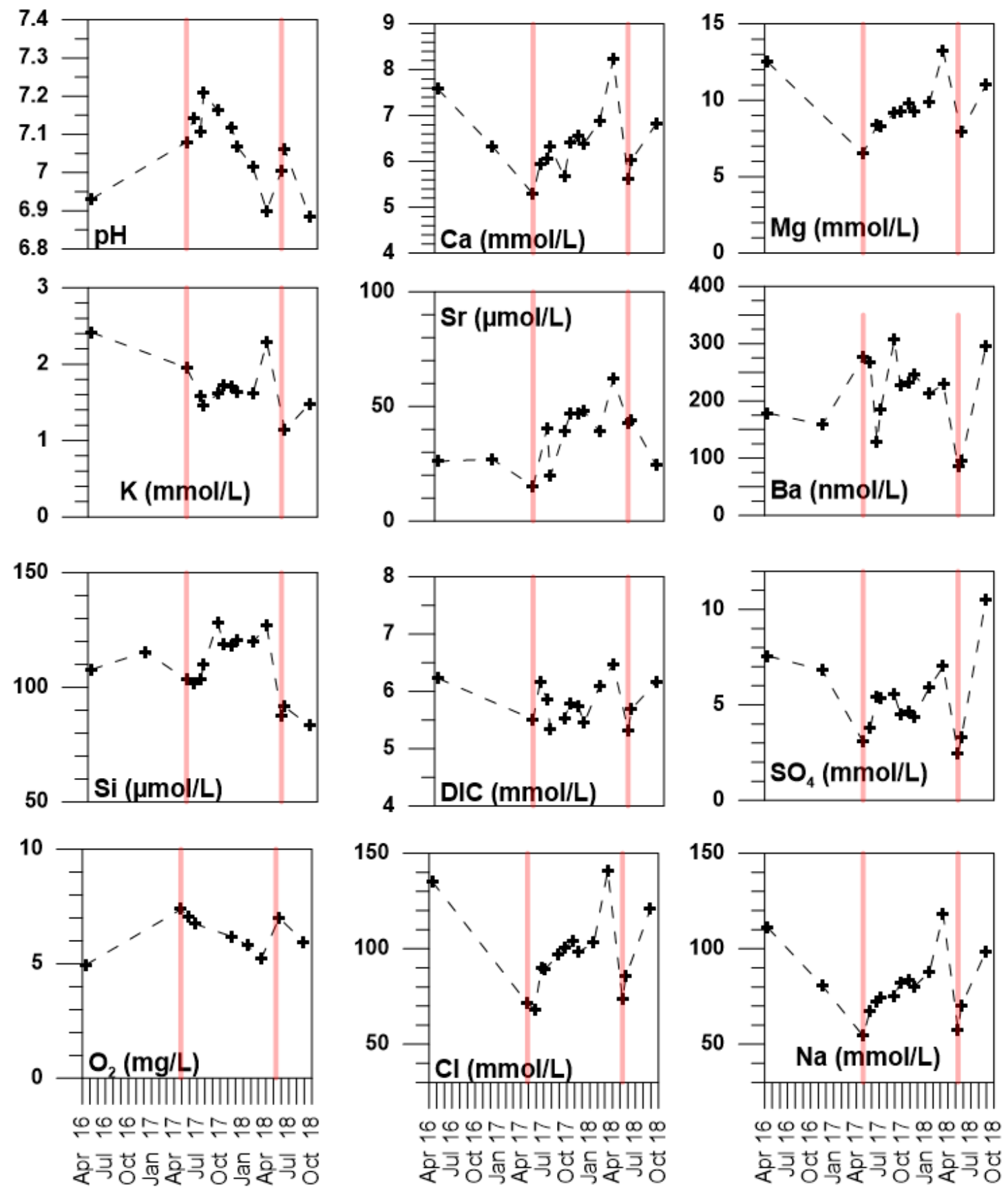

Figure 3. Variation with time of $\mathrm{pH}, \mathrm{ORP}$ and the element concentrations of the La Palme Lavoir karstic spring. The vertical red lines highlight the dates of the minima in salinity ( $\mathrm{S}=4.8$ on April 28, 2017 and $S=4.7$ on May 11, 2018). 

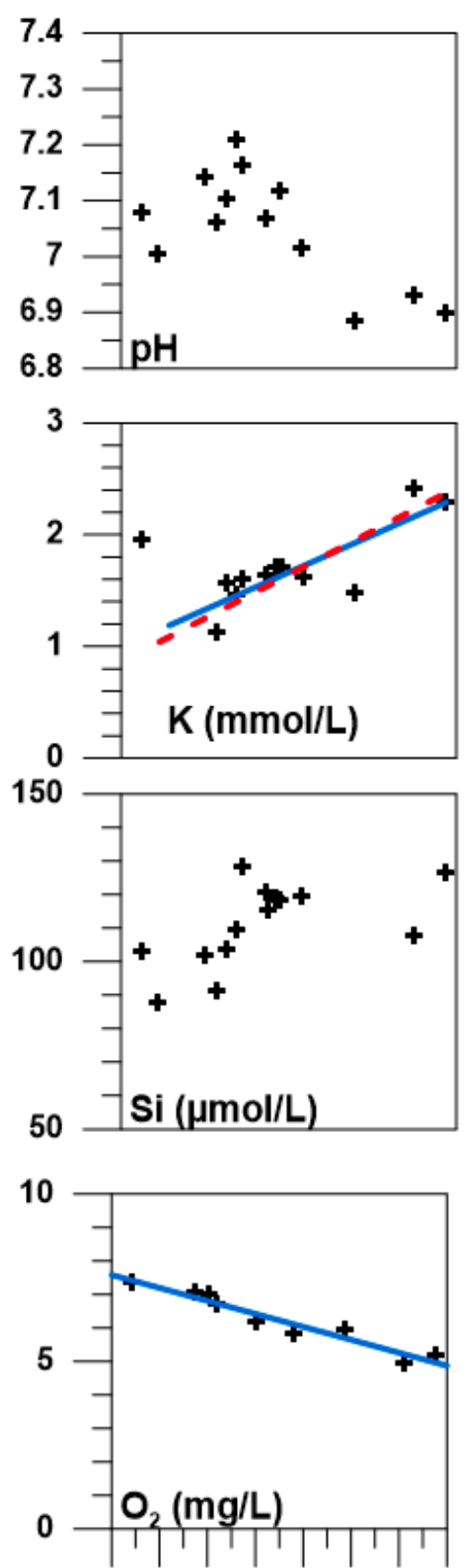

은 웅ㅇㅇㅇ으은 온 $\mathrm{Na}(\mathrm{mmol} / \mathrm{L})$
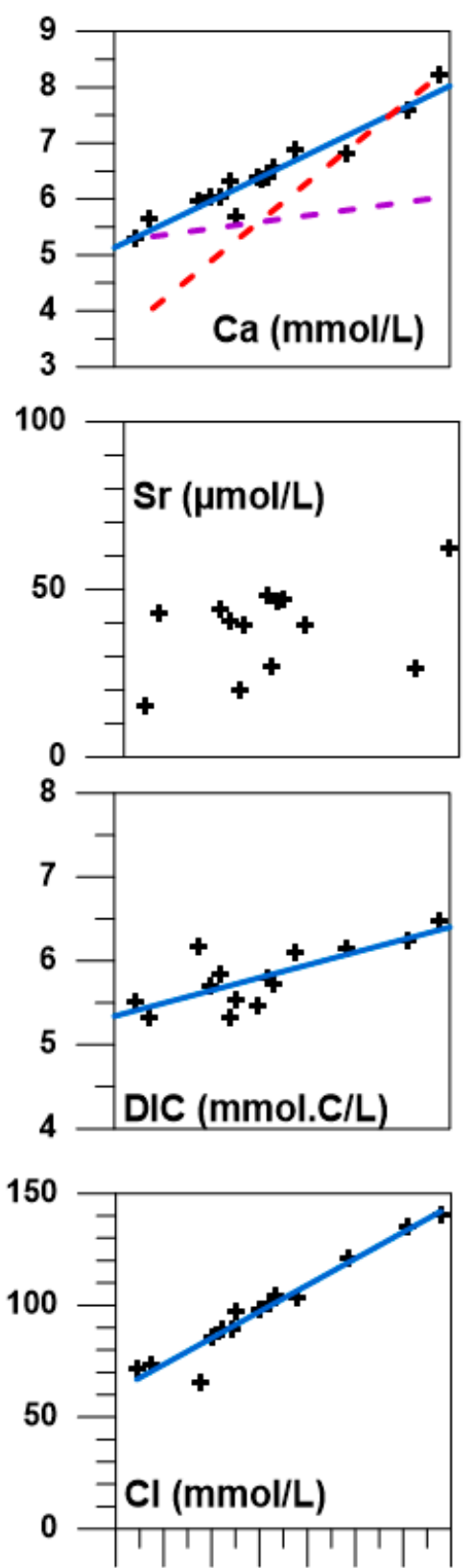

응ㅇㅇㅇㅇㅇㅇ으은 운 $\mathrm{Na}(\mathrm{mmol} / \mathrm{L})$
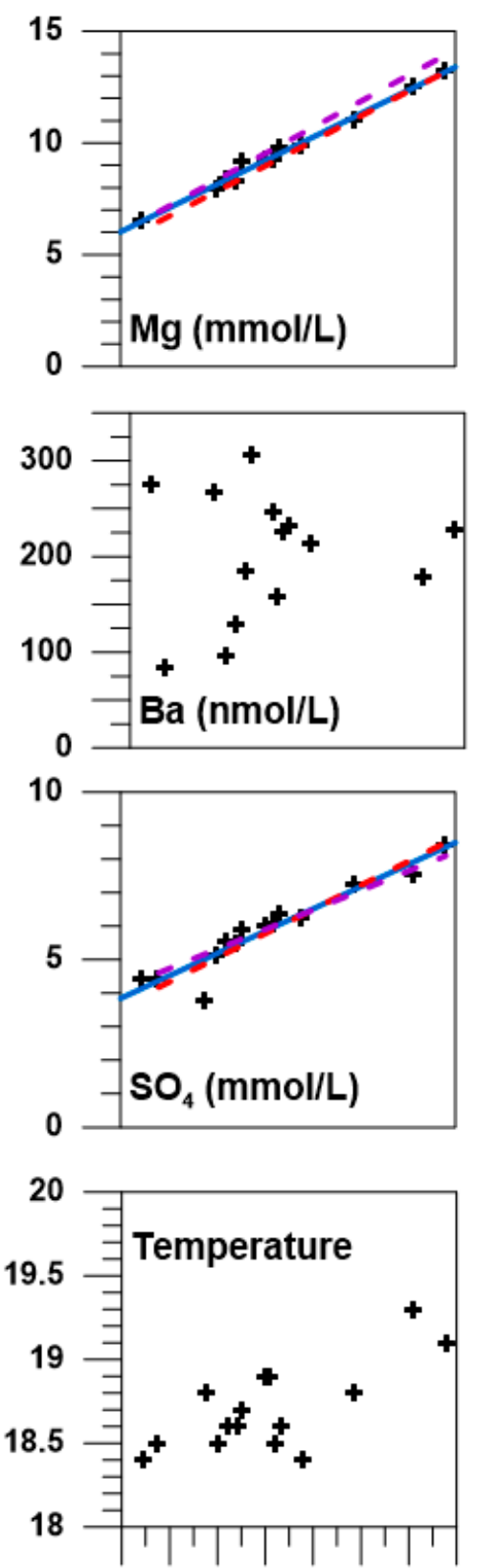

ㅇํㅇㅇㅛ 요으은 은

$\mathrm{Na}(\mathrm{mmol} / \mathrm{L})$

Figure 4. Parameters measured in situ (salinity, $\mathrm{pH}$, temperature, dissolved oxygen) and element concentrations versus the Na content of the karstic spring waters. The blue solid lines are linear fits to the data meant to outline the trends. The red dashed lines are calculated for the case where the highest salinity spring water (salinity 9.4) is diluted by freshwater infiltration. The purple dashed lines represent the variation of the element concentrations when modern seawater (salinity 38 for the Mediterranean Sea) contaminates the spring water with the lowest salinity (salinity 4.7). 

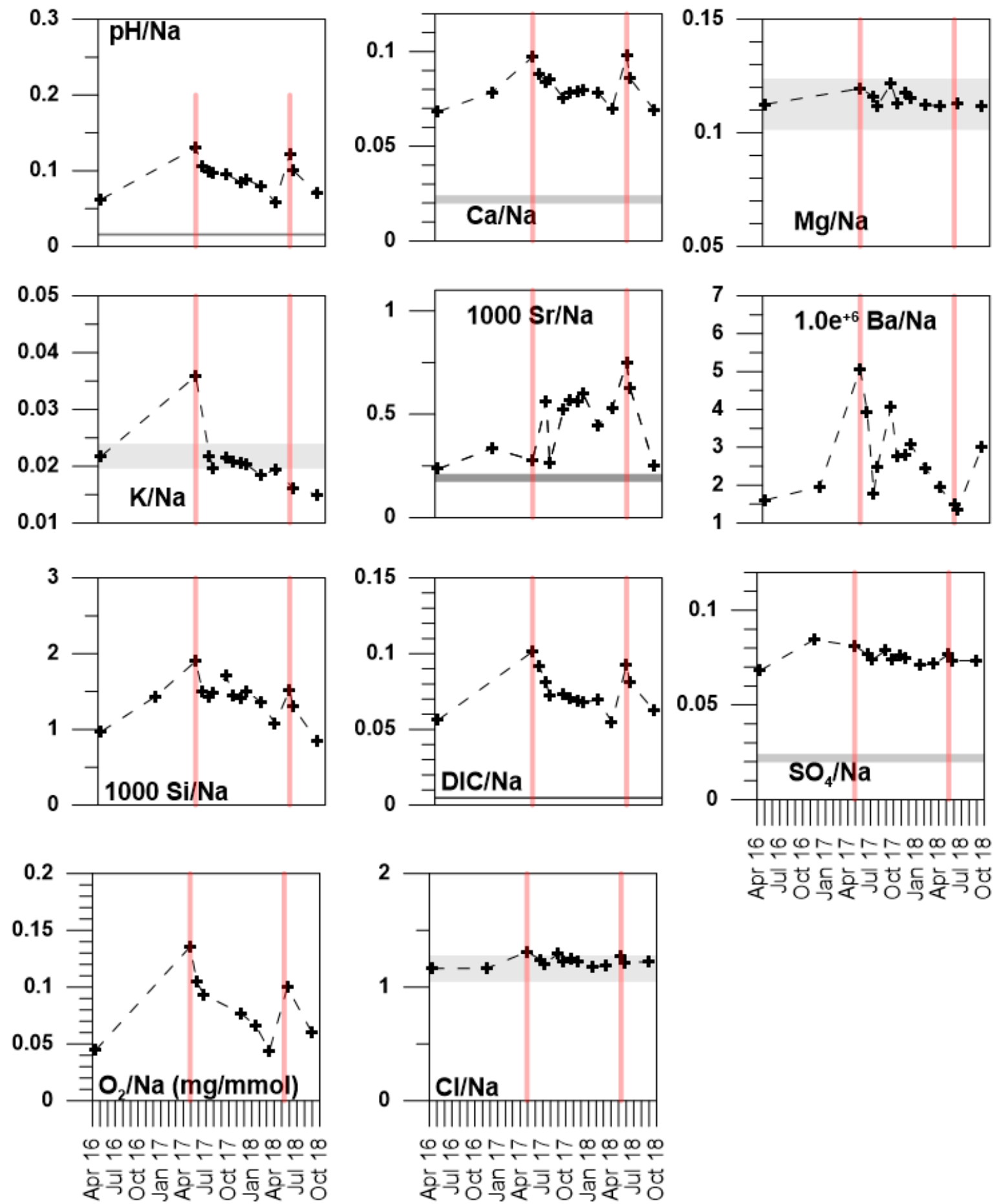

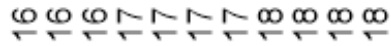

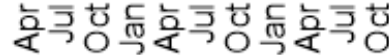

Figure 5. Na-normalized element concentrations of the karstic spring waters over time. The red vertical lines outline the salinity minima on April 28, 2017 and on May 11, 2018. The grey shaded areas correspond to concentration values within $\pm 10 \%$ of those for standard seawater [33]. The retained values used to generate the grey areas for standard seawater are 8.2 for $\mathrm{pH}$ and $2.3 \mathrm{mmol} / \mathrm{L}$ for DIC. No standard concentration for $\mathrm{Si}, \mathrm{Ba}$, and $\mathrm{O}_{2}$ in seawater can be defined, although a $\mathrm{Ba}$ concentration value of $40 \mathrm{nM}$ is characteristic of the Mediterranean sea [38]. 


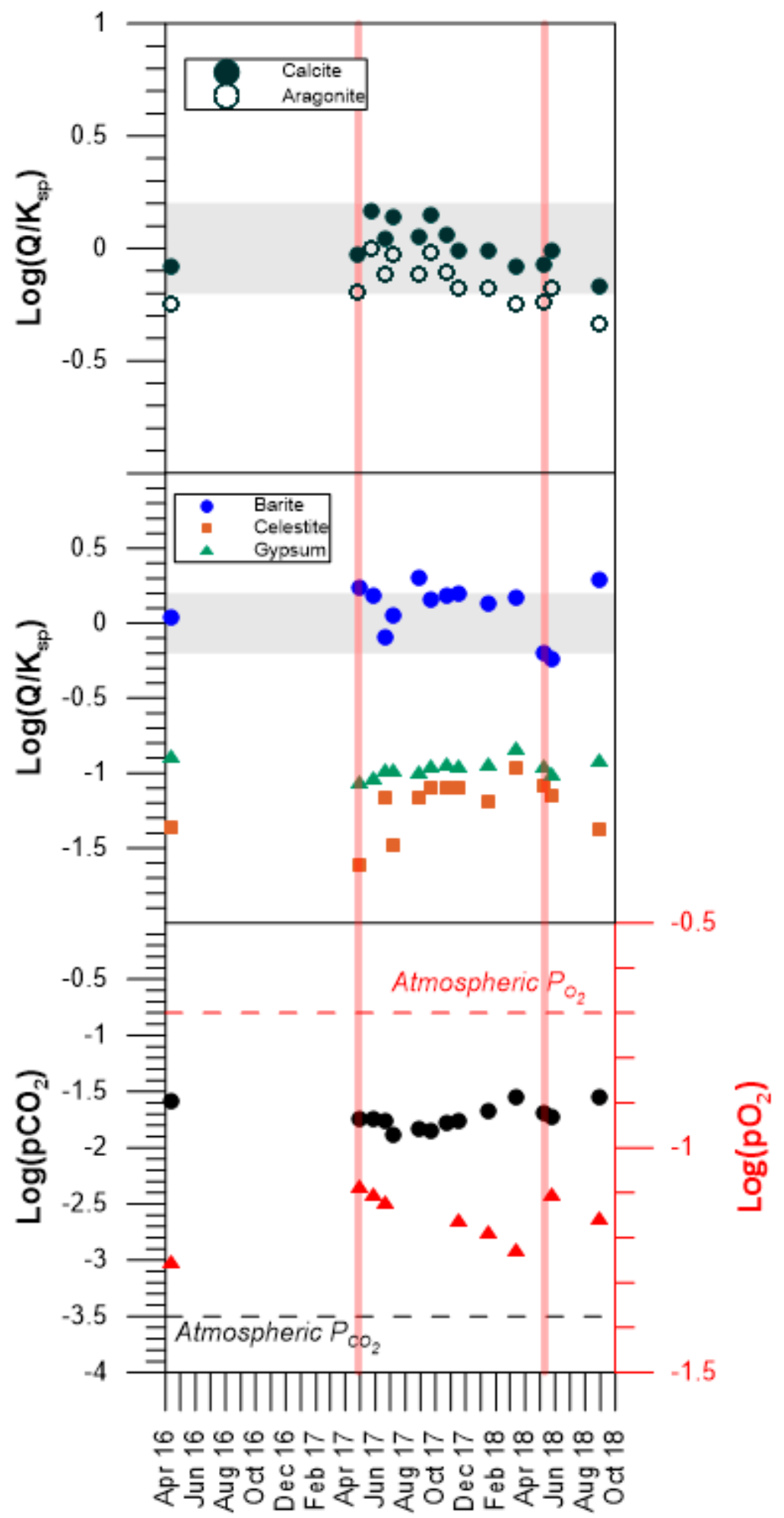

Figure 6. Saturation states of Ca-carbonates (calcite and aragonite) and of sulfate minerals (barite, celestite, and gypsum) along with the logarithm of the equilibrium $\mathrm{CO}_{2}$ and $\mathrm{O}_{2}$ partial pressures for the karstic spring. The shaded areas represent the saturation state range within which equilibrium is assumed $( \pm 0.2)$. The dashed lines are the atmospheric $\mathrm{CO}_{2}$ and $\mathrm{O}_{2}$ partial pressure $\left(\log \mathrm{pCO}_{2}(\mathrm{~atm})\right.$ $\left.=-3.5 ; \log \mathrm{pO}_{2}(\mathrm{~atm})=-0.7\right)$. The two vertical lines point to the dates of salinity minima. Note the missing celestite datum for May 2017 (Table 1). 


\section{Discussion}

\subsection{Temporal and Spatial Variability}

There is no apparent relationship between precipitation events and the composition changes of the spring water (Figures 2 and 4). However, our observations were collected at irregular time intervals, between 2 and 6 weeks, while the precipitation regime is reported as daily averages. We thus cannot exclude that rapid changes in the salinity of the spring water takes place at higher frequency in response to precipitation events. Indeed, we have observed that the flow-rate of the spring had increased after rainy periods. This latter observation would also indicate a very rapid response of the karst aquifer to freshwater infiltration. In comparison, the water temperature of the spring is buffered at values around $18.5^{\circ} \mathrm{C}$ (Figure 2), which indicates a residence time of the waters in the subsurface sufficiently long for thermal equilibration and damping of the temperature variation of the waters feeding the aquifer [39]. It is difficult to address the problem of the aquifer's response to infiltration without coupled high-frequency spring flow-rate and precipitation measurements (e.g., [40,41]).

At a regional scale, karstic systems south of the La Palme watershed have been thoroughly investigated by the French Geological Survey [42]. The response time of the nearby Font Estramar and Font Dame springs, located about $14 \mathrm{~km}$ south of La Palme lagoon, to rainfall has been estimated to be between 20 to 40 days. This response time is comparable to the frequency of our observations, but such a similarity is not relevant, since a marked hydrological barrier south of the La Palme basin, which separates it from Leucate lagoon, has been identified [42]. Moreover, monthly observations have been found inadequate to assess the variability in dissolved element concentrations such as nutrients in coastal aquifers of the Balearic Islands [43]. Monitoring the spring water composition at a higher frequency is thus needed in order to constrain the response of the aquifer to rainfall. At a larger regional scale, Petelet-Giraud et al. [44] have shown that the Roussillon sedimentary basin (about 30 $\mathrm{km}$ south of the La Palme watershed) is a complex multi-layer aquifer whose layers are not equally affected by salinization, with contributions of waters of different origins (fresh water, modern seawater, paleo-groundwaters) and different residence times. The La Clape massif ( $\sim 30 \mathrm{~km}$ northeast of La Palme Lagoon) is a coastal limestone formation whose waters have been characterized as mixtures of local recharge waters with saline waters, either modern seawater or paleo-groundwater [7]. Further north (70 km from La Palme), the Vise spring in Thau lagoon is also a mixture of karstic fresh and saline waters, but with a geothermal component [45]. These studies show that springs located in similar geological environments (coastal karsts) exhibit different degrees of water salinity (due to varying modern seawater or paleo-groundwater contributions) and that the dynamics of these salinity anomalies and therefore the water residence times within the geological formations are difficult to assess [46].

\subsection{The Different Water Types in the La Palme Aquifer—Defining the Endmembers}

In the absence of precipitation/flow data, some indications of the watershed hydrologic regime can be deduced from the spring water chemical composition. Chemical tracers such as $\mathrm{H}$ and $\mathrm{O}$ isotopes are classical examples of chemical tracers of common use in hydrology $[9,10]$. The use of a detailed composition of the waters is more uncommon due to the burden of extensive chemical analyses. In general, apart from the peculiar case of evaporite dissolution, salinity variations are due to the mixing of water bodies of contrasted salinities. Chemical tracers of this mixing must be conservative, i.e., their concentration must not be affected by mineral formation, dissolution, or biological consumption during mixing. As a result, the first question to address when using dissolved elements or compounds as hydrological tracers is the eventual control of their concentration by a chemical equilibrium either with a mineral, or in the case of gases, with the atmosphere.

The Na-normalized element concentrations for the karstic spring (Figure 5) show that the brackish waters are fundamentally different from modern seawater. Several Na-normalized concentrations $(\mathrm{Mg} / \mathrm{Na}$ and to a lesser extend $\mathrm{K} / \mathrm{Na}$ ) may point to a marine origin, but the waters have high carbonate 
and calcium contents, consistent with a control by a chemical equilibrium with Ca-carbonate minerals, as shown by the calcite and aragonite saturation indices (Figure 6). They also have an equilibrium $\mathrm{pCO}_{2}$ about two orders of magnitude higher than the atmospheric value, which indicates that the spring is a source of $\mathrm{CO}_{2}$ to La Palme Lagoon and the atmosphere (Figure 6). Such characteristics are quite common for karstic waters and have been documented many times for springs in the Languedoc-Roussillon region [7,42,45] and elsewhere [31,34]. At a larger scale, Maas and Wicks [36] have shown that the $\mathrm{CO}_{2}$ flux originating from karstic springs is of the same order of magnitude as that from estuaries. The $\mathrm{Sr} / \mathrm{Na}$ ratio is also very different from the seawater value. The $\mathrm{Sr}$ concentration is not controlled by an equilibrium with celestite $\left(\mathrm{SrSO}_{4}\right)$ which is largely undersaturated, as indicated by its $\Omega$ value between -1 and -1.5 (Figure 6$)$. In comparison, barite $\left(\mathrm{BaSO}_{4}\right)$ saturation-state values lie within the range defined as an equilibrium criterion $(-0.2<\Omega<+0.2)$. The barium concentration is thus likely controlled by barite solubility (Figure 6).

The Lavoir spring water is the result of the potential mixing of three water types: (1) paleo-groundwater (the salinity of which may be explained by the Flandrian transgression or other geologic periods [8]), (2) infiltrating rainwater, and (3) modern seawater. The change in the spring water composition can be simulated following two scenarios. We first define $S_{1}$ and $S_{2}$ as the spring water samples displaying the lowest (4.7) and the highest (9.4) salinities, respectively (Table 1). The change in concentration of the conservative dissolved elements can be calculated during (1) the mixing of modern seawater with $S_{1}$, the lowest salinity spring water and (2) the dilution of $S_{2}$, the most saline water by rainwater. The spring water Na concentration is used to quantify the dilution between these different endmembers. This requires the characterization of the two endmembers, rain and standard seawater. We assume that the infiltrating water is rain water, of salinity zero, at equilibrium with the atmosphere $\left(\mathrm{O}_{2}\right.$ and $\left.\mathrm{CO}_{2}\right)$ and with negligible concentrations of dissolved species, which makes it close to pure water. Standard concentrations for seawater can be defined only for the major elements $\left(\mathrm{Na}, \mathrm{K}, \mathrm{Ca}, \mathrm{Mg}, \mathrm{Cl}, \mathrm{SO}_{4}\right)$ and for $\mathrm{Sr}$, all other elements or species being variable in the ocean. The dilution curves displayed in Figure 4 have thus been calculated only for $\mathrm{K}, \mathrm{Ca}, \mathrm{Mg}$, and $\mathrm{SO}_{4}$.

\subsubsection{Seawater Intrusion into $S_{1}$}

Using the Na concentration as a measure of dilution of the $S_{1}$ sample by the addition of seawater, $f_{i}$, the dilution factor between $S_{1}$ (the lowest salinity spring water) and the $i$ th sample can be expressed as:

$$
f_{i}=\frac{C_{N a, i}-C_{N a, s w}}{C_{N a, S_{1}}-C_{N a, s w}}
$$

where $C_{N a, i}$ is the sodium concentration of the designated water sample and $C_{N a, s w}$ is the concentration of $\mathrm{Na}$ in seawater.

The concentration of element $X$ after the supply of seawater to $S_{1}$ leading to the $i$ th spring water sample is:

$$
\mathrm{C}_{\mathrm{X}, \mathrm{i}}=\mathrm{C}_{\mathrm{X}, \mathrm{S}_{1}}+\mathrm{f}_{\mathrm{i}} \cdot\left(\mathrm{C}_{\mathrm{X}, \mathrm{sw}}-\mathrm{C}_{\mathrm{X}, \mathrm{S}_{1}}\right)
$$

In Equation (3) $C_{X, i}, C_{X, S_{1}}$, and $C_{X, s w}$ are the concentrations of element or compound $X$ in the ith spring water sample, in $S_{1}$ and in seawater, respectively.

\subsubsection{Rain Infiltration Diluting $S_{2}$}

Starting from the sample with the highest salinity $\left(S_{2}=9.4\right)$, the concentration of dissolved element $\mathrm{X}$ in the ith water sample is:

$$
C_{X, i}=\cdot \frac{C_{N a, i}}{C_{N a, S_{2}}} \cdot C_{X, S_{2}}
$$

This corresponds to the dilution of $\mathrm{S}_{2}$ by rainwater, with a dilution factor calculated from the $\mathrm{Na}$ concentrations of the considered water sample and the endmember $S_{2}$. 


\subsection{Discussion of the Two Hypotheses}

Both scenarios (mixing of modern seawater with spring water displaying the lowest salinity or the dilution of the most saline water by rainwater) are able to reproduce the observed changes in $\mathrm{K}$, $\mathrm{Mg}$, and $\mathrm{SO} 4$ (Figure 4). The observed $\mathrm{Ca}$ concentrations are higher than the calculated concentrations in both cases (Figure 4). This means that there is a Ca supply to the aquifer water aside from rain infiltration or seawater intrusion. Part of this Ca supply to the aquifer water can be provided by the dissolution of gypsum or anhydrite that indeed are found in the outcrops of the La Palme geologic formation. In this case, gypsum or anhydrite dissolution would also provide $\mathrm{SO}_{4}$ to the aquifer waters, so that the two dilution trends would be different from that for the observed values. This is not what is observed (Figure 4). The Na-normalized $\mathrm{SO}_{4}$ concentration is nevertheless higher than the seawater value, similarly to that of calcium, which may be indicative of the Ca-sulfate dissolution (Figure 5).

Another hypothesis to explain the observed high Ca values is the main process leading to karst formation: the dissolution of Ca carbonates upon infiltration of undersaturated waters, rain water on one side or seawater on the other. This dissolution would also bring the spring waters close to equilibrium with aragonite (Figure 6). However, this still does not discriminate between rain infiltration and seawater intrusion as potential mechanisms to explain the observed salinity variation of the spring.

Maximum values of the oxygen content in the spring waters coincide with the salinity minima (Figures 3 and 5). The solubility of oxygen in brackish waters such as these spring waters is around $9 \mathrm{mg} / \mathrm{L}$ at a temperature of $19{ }^{\circ} \mathrm{C}$ [47] and the highest measured dissolved oxygen value observed for the lowest salinity sample is $7.5 \mathrm{mg} / \mathrm{L}$ (Figure 4). There is also a decreasing trend of the dissolved oxygen content with increasing salinity, suggesting oxygen consumption in the subsurface (Figure 4). These observations are consistent with the input of a low salinity, oxygenated water into the aquifer, thus leading to a decrease in salinity and a simultaneous increase of its oxygen content. Oxygen is the first oxidant consumed in the subsurface; groundwaters are thus often hypoxic or anoxic (e.g., [48,49]). In this study, the karstic spring waters always remain well-oxygenated, with concentrations above $5 \mathrm{mg} / \mathrm{L}$ at all times (Figure 3), which is below oxygen saturation at ambient air temperature $(\sim 8 \mathrm{mg} / \mathrm{L})$. When the infiltration of freshwater stops, oxygen is consumed at the same time as the salinity increases back to baseline (brackish) values, such as the highest salinity point $S_{2}$ (see above). This does not mean that seawater intrusion is not taking place (i.e., Figure 4). Our observations suggest that temporally variable seawater intrusion events do not control the salinity changes. The salinity variations are best explained by episodes of infiltrating rainwater that dilutes the brackish water. This is in contrast with the observations by Young et al. [12] who documented a case study in the Yucatan where the infiltration of oxygenated seawater leads to a simultaneous increase in salinity and dissolved oxygen content of inland anoxic groundwaters.

\section{Conclusions}

The Lavoir karstic spring of the La Palme basin displays marked salinity changes, between 4 and 9 that have been documented by a two and a half year survey during which the spring was visited 17 times for in situ measurements and sampling. The determination of the composition of the spring water (Na-K-Ca-Mg-Ba-Sr-Cl-SO 4 -DIC) has shown that the spring water does not derive from a simple dilution of standard seawater. Chemical equilibria between the water and Ca-carbonates (calcite and aragonite) and barite control the dissolved inorganic carbon (DIC) and barium content of the waters. The elevated DIC values and low $\mathrm{pH}$ (around 7) lead to an equilibrium $\mathrm{pCO}_{2}$ of the spring water about two orders of magnitude larger than the atmospheric values, showing that the spring likely constitutes a $\mathrm{CO}_{2}$ source to the atmosphere.

The salinity variation of the spring water could be due to the competing effects of a freshening of the brackish groundwater by freshwater infiltration (precipitation) and a salinity increase of a fresh groundwater by temporally variable seawater intrusion. The simultaneous increase in oxygen content and decrease in salinity of the spring water suggests that the brackish aquifer is episodically diluted by freshwater (rain) that infiltrates into the karst. Finally, from the methodological point of view, in the 
absence of high-frequency long-term monitoring of the spring flow-rate (coupled to the precipitation record), insight into the hydrologic regime of a coastal karst aquifer can be obtained from simple in situ measurements such as the salinity and oxygen content of spring waters.

Author Contributions: Conceptualization, C.M., P.v.B., J.T.; Methodology, C.M., P.v.B., J.T., M.S.; Investigation, all authors; Writing-Original Draft Preparation, C.M.; Writing-Review \& Editing, C.M., P.v.B., J.T., P.O.; Supervision, C.M., J.T., P.v.B.; Project Administration, and Funding Acquisition, P.v.B.

Funding: This work is part of the MED-SGD project (ANR-15-CE01-0004; P.I.: Pieter van Beek) funded by the French Agence Nationale de la Recherche (ANR). The postdoctoral fellowship of Joseph Tamborski and the PhD thesis of Simon Bejannin are supported by FEDER funded by Europe and Région Occitanie Pyrénées-Méditerranée (SELECT project).

Acknowledgments: We are very grateful to Philippe Besson and Carole Causserand who carried out the chemical analyses at Geosciences Environnement Toulouse (GET laboratory) and to Kattalin Fortuné-Sans and Camille Pfleger (Parc Regional de la Narbonnaise en Méditerranée) for their help and their continuous interest in this project. We thank the anonymous reviewers for their suggestions and Karen Knee for her very efficient editorial work.

Conflicts of Interest: We declare no conflict of interest of any kind.

\section{References}

1. Webb, M.D.; Howard, K.W.F. Modeling the Transient Response of Saline Intrusion to Rising Sea-Levels. Ground Water 2011, 49, 560-569. [CrossRef]

2. Post, V.E.A.; Werner, A.D. Coastal aquifers: Scientific advances in the face of global environmental challenges. J. Hydrol. 2017, 551, 1-3. [CrossRef]

3. Fleury, P.; Bakalowicz, M.; de Marsily, G. Submarine springs and coastal karst aquifers: A review. J. Hydrol. 2007, 339, 79-92. [CrossRef]

4. Newton, A.; Icely, J.; Cristina, S.; Brito, A.; Cardoso, A.C.; Colijn, F.; Riva, S.D.; Gertz, F.; Hansen, J.W.; Holmer, M.; et al. An overview of ecological status, vulnerability and future perspectives of European large shallow, semi-enclosed coastal systems, lagoons and transitional waters. Estuar. Coast. Shelf Sci. 2014, 140, 95-122. [CrossRef]

5. Moosdorf, N.; Oehler, T. Societal use of fresh submarine groundwater discharge: An overlooked water resource. Earth-Sci. Rev. 2017, 171, 338-348. [CrossRef]

6. Custodio, E. Coastal aquifers of Europe: An overview. Hydrogeol. J. 2010, 18, 269-280. [CrossRef]

7. Khaska, M.; La Salle, C.L.G.; Lancelot, J.; ASTER team; Mohamad, A.; Verdoux, P.; Noret, A.; Simler, R. Origin of groundwater salinity (current seawater vs. saline deep water) in a coastal karst aquifer based on $\mathrm{Sr}$ and $\mathrm{Cl}$ isotopes. Case study of the La Clape massif (southern France). Appl. Geochem. 2013, 37, 212-227. [CrossRef]

8. Bakalowicz, M. Karst and karst groundwater resources in the Mediterranean. Environ. Earth Sci. 2015, 74, 5-14. [CrossRef]

9. Todd, D.K.; Mays, L.W. Groundwater Hydrology, 3rd ed.; John Wiley and Sons: Hoboken, NJ, USA, 2005; p. 636.

10. Schwartz, F.W.; Zhang, H. Fundamentals of Groundwater; John Wiley and Sons: Hoboken, NJ, USA, 2003; p. 582.

11. Dimova, N.; Ganguli, P.M.; Swarzenski, P.W.; Izbicki, J.A.; O’Leary, D. Hydrogeologic controls on chemical transport at Malibu Lagoon, CA: Implications for land to sea exchange in coastal lagoon systems. J. Hydrol. 2017, 11, 219-233. [CrossRef]

12. Young, C.; Martin, J.B.; Branyon, J.; Pain, A.; Valle-Levinson, A.; Mariño-Tapia, I.; Vieyra, M.R. Effects of short-term variations in sea level on dissolved oxygen in a coastal karst aquifer, Quintana Roo, Mexico. Limnol. Oceanogr. 2018, 63, 352-362. [CrossRef]

13. Russak, A.; Sivan, O.; Yechieli, Y. Trace elements (Li, B, Mn and Ba) as sensitive indicators for salinization and freshening events in coastal aquifers. Chem. Geol. 2016, 441, 35-46. [CrossRef]

14. Mongelli, G.; Monni, S.; Oggiano, G.; Paternoster, M.; Sinisi, R. Tracing groundwater salinization processes in coastal aquifers: A hydrogeochemical and isotopic approach in the $\mathrm{Na}-\mathrm{Cl}$ brackish waters of northwestern Sardinia, Italy. Hydrol. Earth Syst. Sci. 2013, 17, 2917-2928. [CrossRef] 
15. Hebrard, O.; Pistre, S.; Cheynet, N.; Dazy, J.; Batiot-Guilhe, C.; Seidel, J.-L. Origin of the Languedoc-Roussillon's chloride rich karstic spring waters. Comptes Rendus Geosci. 2006, 338, 703-710. [CrossRef]

16. Tamborski, J.; Bejannin, S.; Garcia-Orellana, J.; Souhaut, M.; Charbonnier, C.; Anschutz, P.; Pujo-Pay, M.; Conan, P.; Crispi, O.; Monnin, C.; et al. A comparison between water circulation and terrestrially-driven dissolved silica fluxes to the Mediterranean Sea traced using radium isotopes. Geochimica et Cosmochimica Acta 2018, 238, 496-515. [CrossRef]

17. Bejannin, S.; van Beek, P.; Thomas, S.; Marc, S.; Joseph, T. Combining airborne thermal infrared images and radium isotopes to study submarine groundwater discharge along the French Mediterranean coastline. J. Hydrol. 2017, 13, 72-90. [CrossRef]

18. Stieglitz, T.C.; Beek, P.; Souhaut, M.; Cook, P.G. Karstic groundwater discharge and seawater recirculation through sediments in shallow coastal Mediterranean lagoons, determined from water, salt and radon budgets. Mar. Chem. 2013, 156 (Suppl. C), 73-84. [CrossRef]

19. Tamborski, J.; van Beek, P.; Rodellas, V.; Monnin, C.; Bergsma, E.; Stieglitz, T.; Heilbrun, C.; Cochran, J.K.; Charbonnier, C.; Anschutz, P.; et al. Temporal variability of lagoon-sea water exchange and seawater circulation through a Mediterranean barrier beach. Limnol. Oceanogr. 2019. [CrossRef]

20. Berger, G.M.; Bertrand-Sarfati, J.; Ovtracht, A.; Héraud, H.; de Bouchony, P.; Tourel, Y.; Got, H.; Le Bail, A.; Blès, J.-L.; Gadel, F.; et al. Carte Geologique de la France a 1/50 000, Feuille Leucate (1079); BRGM: Orleans, France, 1982.

21. Khaska, M.; La Salle, C.L.G.; Videau, G.; Flinois, J.-S.; Frape, S.; Aster Team; Verdoux, P. Deep water circulation at the northern Pyrenean thrust: Implication of high temperature water-rock interaction process on the mineralization of major spring water in an overthrust area. Chem. Geol. 2015, 419, 114-131. [CrossRef]

22. Parkhurst, D.L.; Appelo, C.A.J. Description of input and examples for PHREEQC version 3-A computer program for speciation, batch-reaction, one-dimensional transport, and inverse geochemical calculations. In U.S. Geological Survey Techniques and Methods; USGS: Reston, VA, USA, 2013; Book 6, Chapter A43; pp. 1-497.

23. Giffaut, E.; Grivé, M.; Blanc, P.; Vieillard, P.; Colàs, E.; Gailhanou, H.; Gaboreau, S.; Marty, N.; Madé, B.; Duro, L. Andra thermodynamic database for performance assessment: ThermoChimie. Appl. Geochem. 2014, 49, 225-236. [CrossRef]

24. Blanc, P.; Bourbon, X.; Lassin, A.; Gaucher, E.C. Chemical model for cement-based materials: Thermodynamic data assessment for phases other than C-S-H. Cem. Concr. Res. 2010, 40, 1360-1374. [CrossRef]

25. Blanc, P.; Lassin, A.; Piantone, P.; Azaroual, M.; Jacquemet, N.; Fabbri, A.; Gaucher, E.C. Thermoddem: A geochemical database focused on low temperature water/rock interactions and waste materials. Appl. Geochem. 2012, 27, 2107-2116. [CrossRef]

26. Marion, G.M.; Mironenko, M.V.; Roberts, M.W. FREZCHEM: A geochemical model for cold aqueous solutions. Comput. Geosci. 2010, 36, 10-15. [CrossRef]

27. Marion, G.M.; Kargel, J.S. Cold Aqueous Planetary Geochemistry with FREZCHEM: From Modeling to the Search for Life at the Limits; Springer: New York, NY, USA, 2008.

28. Benezeth, P.; Berninger, U.-N.; Bovet, N.; Schott, J.; Oelkers, E.H. Experimental determination of the solubility product of dolomite at 50-253 degrees C. Geochimica et Cosmochimica Acta 2018, 224, 262-275. [CrossRef]

29. Oehlerich, M.; Mayr, C.; Griesshaber, E.; Lücke, A.; Oeckler, O.M.; Ohlendorf, C.; Schmahl, W.W.; Zolitschka, B. Ikaite precipitation in a lacustrine environment-Implications for palaeoclimatic studies using carbonates from Laguna Potrok Aike (Patagonia, Argentina). Quater. Sci. Rev. 2013, 71, 46-53. [CrossRef]

30. Monnin, C.; Hoareau, G. Chemical Equilibrium between Aqueous Fluids and Minerals in the Marine Environment, in Ion-partitioning in Ambient Temperature Aqueous Systems; Prieto, M., Stoll, H., Eds.; European Mineralogical Union: Jena, Germany, 2010; pp. 227-257.

31. Acero, P.; Auqué, L.F.; Galve, J.P.; Gutiérrez, F.; Carbonel, D.; Gimeno, M.J.; Yechieli, Y.; Asta, M.P.; Gómez, J.B. Evaluation of geochemical and hydrogeological processes by geochemical modeling in an area affected by evaporite karstification. J. Hydrol. 2015, 529, 1874-1889. [CrossRef]

32. Power, I.M.; Kenward, P.A.; Dipple, G.M.; Raudsepp, M. Room Temperature Magnesite Precipitation. Crystal Growth Design 2017, 17, 5652-5659. [CrossRef]

33. Millero, F.J. Chemical oceanography. In Marine Sciences Series; Kennish, M.K., Ed.; CRC Taylor and Francis: Abingdon-on-Thames, UK, 2006; p. 496. 
34. Gil-Márquez, J.M.; Barberá, J.A.; Andreo, B.; Mudarra, M. Hydrological and geochemical processes constraining groundwater salinity in wetland areas related to evaporitic (karst) systems. A case study from Southern Spain. J. Hydrol. 2017, 544, 538-554. [CrossRef]

35. Macpherson, G.L. $\mathrm{CO}_{2}$ distribution in groundwater and the impact of groundwater extraction on the global C cycle. Chem. Geol. 2009, 264, 328-336. [CrossRef]

36. Maas, B.J.; Wicks, C.M. $\mathrm{CO}_{2}$ Outgassing from Spring Waters. Aquat. Geochem. 2017, 23, 53-60. [CrossRef]

37. Raymond, P.A.; Hartmann, J.; Lauerwald, R.; Sobek, S.; McDonald, C.; Hoover, M.; Butman, D.; Striegl, R.; Mayorga, E.; Humborg, C.; et al. Global carbon dioxide emissions from inland waters. Nature 2013, 503, 355-359. [CrossRef]

38. Jacquet, S.H.M.; Monnin, C.; Riou, V.; Jullion, L.; Tanhua, T. A high resolution and quasi-zonal transect of dissolved Ba in the Mediterranean Sea. Mar. Chem. 2016, 178, 1-7. [CrossRef]

39. Anderson, M.P. Heat as a Ground Water Tracer. Groundwater 2005, 43, 951-968. [CrossRef]

40. Aquilina, L.; Ladouche, B.; Dorfliger, N. Water storage and transfer in the epikarst of karstic systems during high flow periods. J. Hydrol. 2006, 327, 472-485. [CrossRef]

41. Labat, D.; Mangin, A.; Ababou, R. Rainfall-runoff relations for karstic springs: Multifractal analyses. J. Hydrol. 2002, 256, 176-195. [CrossRef]

42. Ladouche, B.; Dörfliger, N.; Izac, J.L.; Cubizolles, J.; Le Strat, P.; Du Couëdic, C.; Aunay, B.; Thomson, P. Evaluation des Ressources en eau des Corbières. Phase I-Synthèse de la Caractérisation des Systèmes Karstiques des Corbières Orientales. Rapport Final. Volume 2-Caractérisation Géologique et Hydrogéologique du Système Karstqiue du Synclinal du Bas-Agly; BRGM: Orléans, France, 2004; report BRGM/RP-52919-FR; p. 196.

43. Lucena-Moya, P.; Gomez-Rodriguez, C.; Pardo, I. Spatio-Temporal Variability in Water Chemistry of Mediterranean Coastal Lagoons and its Management Implications. Wetlands 2012, 32, 1033-1045. [CrossRef]

44. Petelet-Giraud, E.; Négrel, P.; Aunay, B.; Ladouche, B.; Bailly-Comte, V.; Guerrot, C.; Flehoc, C.; Pezard, P.; Lofi, J.; Dörfliger, N. Coastal groundwater salinization: Focus on the vertical variability in a multi-layered aquifer through a multi-isotope fingerprinting (Roussillon Basin, France). Sci. Total Environ. 2016, 566, 398-415. [CrossRef] [PubMed]

45. Aquilina, L.; Ladouche, B.; Doerfliger, N.; Seidel, J.L.; Bakalowicz, M.; Dupuy, C.; Le Strat, P. Origin, evolution and residence time of saline thermal fluids (Balaruc springs, southern France): Implications for fluid transfer across the continental shelf. Chem. Geol. 2002, 192, 1-21. [CrossRef]

46. Werner, A.D.; Bakker, M.; Post, V.E.A.; Vandenbohede, A.; Lu, C.; Ataie-Ashtiani, B.; Simmons, C.T.; Barry, D.A. Seawater intrusion processes, investigation and management: Recent advances and future challenges. Adv. Water Resour. 2013, 51, 3-26. [CrossRef]

47. Walton Smith, F.G. Handbook of Marine Science; CRC Press: Boca Raton, FL, USA, 1981; p. 627.

48. Chapelle, F.H. Geochemistry of groundwater. In Surface and Groundwater, Weathering, and Soils; Drever, J.I., Ed.; Elsevier-Pergamon: Oxford, UK, 2003; pp. 425-450.

49. Martin, W.R.; Sayles, F.L. 7.02-The Recycling of Biogenic Material at the Seafloor. In Treatise on Geochemistry; Holland, H.D., Turekian, K.K., Eds.; Pergamon: Oxford, UK, 2003; pp. 37-65.

(C) 2019 by the authors. Licensee MDPI, Basel, Switzerland. This article is an open access article distributed under the terms and conditions of the Creative Commons Attribution (CC BY) license (http://creativecommons.org/licenses/by/4.0/). 